\title{
UPR in palmitate-treated pancreatic beta-cells is not affected by altering oxidation of the fatty acid
}

\author{
Ernest Sargsyan*, E-ri Maria Sol and Peter Bergsten
}

\begin{abstract}
Background: Elevated levels of lipids are detrimental for beta-cell function and mass. One of the mechanisms of how fatty acids induce apoptosis is development of the unfolded protein response (UPR). It is still far from understood how fatty acids activate the UPR, however.

Methods: We examined how palmitate-induced activation of the UPR was affected by altering the metabolism of the fatty acid in insulin-secreting INS-1E and MIN6 cell lines and intact human islets. To increase oxidation, we used low glucose $(5.5 \mathrm{mM})$ or AICAR; and to reduce oxidation, we used high glucose ( $25 \mathrm{mM})$ or etomoxir. UPR was measured after 3, 24 and 48 hours of palmitate treatment.

Results: Modulation of palmitate oxidation by either glucose or the pharmacological agents did not affect palmitate-induced UPR activation.

Conclusion: Our finding suggests that other factors than oxidation of palmitate play a role in the activation of UPR in fatty acid-treated beta-cells.
\end{abstract}

Keywords: beta-cell, human islets, palmitate oxidation, ER stress, unfolded protein response

\section{Introduction}

Extended elevated levels of fatty acids impair glucosestimulated insulin secretion (GSIS) and induce apoptosis in insulin-secreting beta-cells $[1,2]$. Various mechanisms of fatty-induced beta-cell apoptosis have been proposed, where development of the unfolded protein response (UPR) has been studied intensely during recent times [3-11]. The UPR or the endoplasmic reticulum (ER) stress response is the adaptive cellular reactions that coordinate down-regulation of overall protein synthesis and increased protein folding capacity by up-regulation of molecular chaperones and enhanced protein degradation [12-15]. Three signaling pathways of UPR, controlled by ER transmembrane proteins PKR-like endoplasmic reticulum kinase (PERK), IRE1 and activating transcription factor (ATF) 6, have been discovered [14]. Under normal conditions, these proteins are inactive due to interaction with molecular chaperone BiP. Accumulation of unfolded proteins leads to dissociation of $\mathrm{BiP}$ and activation of these sensors. Activation of PERK occurs early

\footnotetext{
* Correspondence: Ernest.Sargsyan@mcb.uu.se
Department of Medical Cell Biology, Uppsala University, Box 571, SE-75123,

* Correspondence: Ernest.Sargsyan@mcb.uu.se
Department of Medical Cell Biology, Uppsala University, Box 571, SE-75123, Uppsala, Sweden
} Uppsala, Sweden

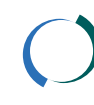

in time and leads to phosphorylation of eukaryotic initiation factor $2 \alpha$ (eIF2 $\alpha)$, which attenuates protein synthesis and, at the same time, stimulates translation of ATF4. ATF4 is a transcription factor that regulates expression of molecular chaperones. IRE1, after activation, catalyzes splicing of XBP1. Spliced form of XBP1 encodes an active transcription factor that regulates expression of molecular chaperones and also proteins involved in degradation and secretion. Activation of ATF6 leads to its translocation to Golgi, where after cleavage with proteases it forms an active transcription factor that controls expression of molecular chaperones. When these mechanisms cannot compensate for the ER stress, cell death pathways are activated. The C/EBP-homologous protein/growth arrest and DNA damage-inducible protein (CHOP/ GADD153) transcription factor and JNK have been implicated in this aspect of the UPR [16]. Proposed mechanisms of how fatty acids induce ER stress include ER $\mathrm{Ca}^{2+}$ release, overload of ER with unfolded proteins and accumulation of tripalmitin in the ER $[17,18]$. In the present study, we examined the role of palmitate metabolism in the fatty acid-triggered activation of UPR in insulin-secreting cell lines INS-1E and MIN6 and intact 
human islets. It is known that reduced oxidation of palmitate directs long chain CoA towards non-oxidative metabolic pathways, such as generation of TAGs and ceramides $[19,20]$. Palmitate oxidation was modified by using various concentrations of glucose. According to the malonyl-CoA hypothesis high glucose reduces fatty acid oxidation, which is due to inhibition of fatty acid transporter CPT1 by increased production of malonyl-CoA $[19,20]$. At low glucose, beta-cells oxidize fatty acids [21]. Additionally, we used AMPK agonist AICAR, which favors fatty acid oxidation and prevents lipotoxicity, and CPT1 inhibitor etomoxir that reduces fatty acid oxidation and aggravates lipotoxicity $[19,22,23]$.

\section{Materials and methods Cell culture}

Rat INS-1E cells (a kind gift from Dr. Pierre Maechler, Geneva University) were cultivated in RPMI 1640 medium containing $11 \mathrm{mM}$ glucose and supplemented with $10 \%$ fetal bovine serum (FBS), $2 \mathrm{mM} \mathrm{L}$-glutamine, $1 \mathrm{mM}$ sodium pyruvate, $10 \mathrm{mM}$ HEPES and $55 \mu \mathrm{M} \beta$ mercaptoethanol at $37^{\circ} \mathrm{C}$ and $5 \% \mathrm{CO}_{2}$. All reagents were purchased from Invitrogen (Carlsbad, CA). Experiments with INS-1E cells were performed between passages 65 and 90. Mouse insulinoma MIN6 cells (a kind gift from Prof. Jun-Ichi Miyazaki, Osaka University) were maintained in Dulbecco's Modified Eagle medium (DMEM) containing $25 \mathrm{mM}$ glucose and supplemented with $10 \% \mathrm{FBS}$ and $55 \mu \mathrm{M} \beta$-mercaptoethanol at $37^{\circ} \mathrm{C}$ and $5 \% \mathrm{CO}_{2}$. All experiments with MIN6 cells were performed between passages 21 and 28. Human islets were obtained from the Islet Transplantation Unit at Uppsala University from non-diabetic individuals. Human islets were cultured in CMRL 1066 medium containing $5.5 \mathrm{mM}$ glucose and supplemented with $10 \%$ FBS.

\section{Ethics Statement}

Ethical permission to use human islets isolated from healthy individuals have been obtained from the Regional Ethical Review Board in Uppsala (date: 2010-02-10; number 2010/006).

\section{Free fatty acid preparation and cell/islet treatment} Culture medium containing palmitate (Sigma, St. Louis, $\mathrm{MO})$ was prepared as previously described $[4,10]$. Briefly, the fatty acid was dissolved in 50\% ethanol to a concentration of $100 \mathrm{mM}$. This stock solution was diluted in culture medium to a required concentration and then allowed to complex with $0.5 \%$ fatty acid free BSA (Boehringer Mannheim $\mathrm{GmbH}$, Mannheim, Germany) for $30 \mathrm{~min}$ at $37^{\circ} \mathrm{C}$. Cells cultured to $65-70 \%$ confluence or $\sim 50$ human islets were exposed to palmitate in the presence of different concentrations of glucose for 48 hours. Whereas FBS was maintained during palmitate exposure of INS-1E and MIN6 cells [10,11], FBS was removed during palmitate incubation of human islets [24]. Cells and islets cultured in the presence of palmitate were also treated with $1 \mathrm{mM}$ AICAR or $0.2 \mathrm{mM}$ etomoxir (both purchased from Sigma).

\section{Measurements of palmitate oxidation rate}

Cells/islets were cultured in media containing $0.5 \mathrm{mM}$ palmitate and $2 \mu \mathrm{Ci}\left[{ }^{3} \mathrm{H}\right]$ palmitate per $\mathrm{ml}$. To measure oxidation, media samples were collected after culture and ${ }^{3} \mathrm{H}_{2} \mathrm{O}$ separated from $\left[{ }^{3} \mathrm{H}\right]$ palmitate using Folch extraction [25]. The volume of $10 \mathrm{ml}$ Ultima Gold ${ }^{\mathrm{TM}}$ scintillation fluid (Chemical Instruments $\mathrm{AB}$, Sollentuna, Sweden) was added to $500 \mu \mathrm{l}^{3} \mathrm{H}_{2} \mathrm{O}$ and radioactivity determined by a liquid-scintillation spectrometer (Wallac System $1400^{\mathrm{TM}}$ PerkinElmer, Boston, MA). The results were normalized to DNA content.

\section{Protein measurements by Western blot analysis}

Details of the procedure for immunoblotting have been described previously [26]. Immunoblot analyses were performed with antibodies towards phosphorylated PERK (p-PERK), phosphorylated eIF2 $\alpha$ (p-eIF2 $\alpha$ ) (Cell Signaling, Beverly, MA), CHOP/GADD153 (Santa Cruz Biotechnology, Santa Cruz, CA) and BiP/GRP78 (Abcam, Cambridge, UK) [27]. Immuno-reactive bands were visualized with Fluor-S Multilmager MAX (BioRad, Hercules, CA) and quantified with Quantity One software (Bio-Rad).

\section{Analysis of mRNA expression by real-time PCR}

Total mRNA was isolated from the cells by Trizol (Invitrogen) and reversely transcribed with SuperScript ${ }^{\mathrm{TM}}$ III First-Strand Synthesis System for RT-PCR (Invitrogen). The real-time PCR was performed in $10 \mu$ l volume containing $\sim 20 \mathrm{ng}$ cDNA, $0.5 \mu \mathrm{M}$ forward and reverse primers and $5 \mu \mathrm{l}$ Dynamo Capillary SYBR Green qPCR kit (Finnzymes, Espoo, Finland). Primers used for the amplification are shown in Table 1. PCR products were quantified fluorometrically using SYBR Green and normalized to the housekeeping gene $\beta$-actin and relative to the control (11 mM glucose). The following formula was used: target amount $=2^{-\Delta \Delta C t}$, where $\Delta \Delta C t=\{[C t$ (target gene sample) - $C t$ ( $\beta$-actin sample) $]$ - [Ct (control sample) - $C t$ ( $\beta$-actin control)\} [28].

\section{Statistical analysis}

Results are presented as means \pm SEM. Statistical significance between two conditions was analyzed using oneway ANOVA with Tukey post-hoc test. $P<0.05$ was considered statistically significant. 
Table 1 Primers used for real-time PCR

\begin{tabular}{|c|c|c|}
\hline Target & Forward primer & Reverse primer \\
\hline b-actin & 5'-TCTGTGTGGATTGGTGGCTC-3' & 5'-GACTCATCGTACTCCTGCTTGCT-3' \\
\hline CHOP/GADD153 & 5'-CCAGCAGAGGTCACAAGCAC-3' & 5'-CGCACTGACCACTCTGTTTC-3' \\
\hline GADD34 & 5'-GTCCATTTCCTTGCTGTCTG-3' & 5'-AAGGCGTGCCCATGCTCTGG-3' \\
\hline ATF4 & 5'-GTTGGTCAGTGCCTCAGACA-3' & 5'-CATTCGAAACAGAGCATCGA-3' \\
\hline Spliced XBP1 rat & 5'-GAGTCCGCAGCAGGTG-3' & 5'-GCGTCAGAATCCATGGGA -3' \\
\hline EDEM & $5^{\prime}$-CAGTCAAGTTAGTGATCAACAC- $3^{\prime}$ & $5^{\prime}-$ TGTCATGTCACCAAAGGGCTG - 3' \\
\hline
\end{tabular}

\section{Results}

Palmitate oxidation is reduced by high glucose in human islets, MIN6 cells and INS-1E cells

Palmitate oxidation was measured in palmitate-exposed human islets, MIN6 and INS-1E cells cultured at 5.5 (low) or 25 (high) $\mathrm{mM}$ glucose for 3, 24 or 48 hours. In human islets (Figure 1A) and MIN6 cells (Figure 1B) cultured at high glucose palmitate oxidation was lowered by about $30 \%$ compared to islets and cells cultured at low glucose. In human islets reduced oxidation of the fatty acid in the presence of high glucose compared to low glucose was already detected after 3 hours. In INS$1 \mathrm{E}$ cells exposed to palmitate for 24 or 48 hours oxidation rate of the fatty acid was reduced by $80 \%$ in cells cultured at high glucose compared to cells cultured at low glucose (Figure 1C). After 3 hours, palmitate oxidation in INS-1E cells cultured at low and high glucose was similar. Addition of AICAR partially restored the glucose-dependent reduction in palmitate oxidation in INS-1E cells (Figure 1C) but not in human islets and MIN6 cells (Figures $1 \mathrm{~A}$ and $1 \mathrm{~B}$ ). When etomoxir was added palmitate oxidation was reduced in both cell lines and islets (Figure 1).

Palmitate-induced UPR is not affected by high glucose in human islets, MIN6 cells or INS-1E cells

Translational attenuation is an early event of the UPR and is achieved via the phosphorylation of PERK and eIF2 $\alpha$ [29]. In human islets and MIN6 cells exposed to palmitate levels of p-eIF $2 \alpha$ rose approximately 2 -fold after 3 hours and continued to rise in MIN6 cells $(\mathrm{P}<$ 0.05 ) but not in islets up to 48 hours (Figures 2A and 3A; additional files $1 \mathrm{~A}$ and $1 \mathrm{~B}$ ). Levels of p-eIF2 $\alpha$ levels in human islets and MIN6 cells exposed to palmitate were neither changed by altering the glucose concentration nor by adding AICAR or etomoxir. If ER stress is not alleviated, activation of the PERK pathway leads to upregulation of pro-apoptotic protein $\mathrm{CHOP}$ [30]. When protein levels of CHOP were measured in human islets and MIN6 cells, no alterations were observed after 3 hours (Figures $2 \mathrm{~B}$ and $3 \mathrm{~B}$; additional files $1 \mathrm{~A}$ and $1 \mathrm{~B}$ ). After 24 and 48 hours, palmitate caused 2-3 fold induction in the expression level of CHOP, however. The induction was neither dependent on glucose nor etomoxir or AICAR concentrations. Potential activation of IRE1 and ATF6 signaling was examined by measuring expression level of $\mathrm{BiP}$ in human islets and MIN6 cells exposed to palmitate. Levels of the chaperone were not altered irrespective of culture time, glucose, AICAR or etomoxir concentrations (Figures $2 \mathrm{C}$ and $3 \mathrm{C}$; additional files $1 \mathrm{~A}$ and $1 \mathrm{~B})$.

Difference in palmitate oxidation observed at low and high glucose was especially marked in INS-1E cells (Figure 1A). UPR in INS-1E cells was therefore studied more thoroughly. When phosphorylation levels of eIF2 $\alpha$ were measured in INS-1E cells cultured in the presence of palmitate, p-eIF $2 \alpha$ levels rose approximately 5 -fold already after 3 hours and remained elevated after 24 and 48 hours (Figure 4B; additional file $1 C)$. The degree of palmitate-induced phosphorylation of eIF2 $\alpha$ was neither affected by the glucose concentration, nor inclusion of AICAR or etomoxir, however. The lack of glucose-dependency made us also measure phosphorylation levels of PERK, the kinase responsible for phosphorylation of eIF2 $\alpha$ [14]. Phosphorylation patterns of PERK were almost identical to those observed of p-eIF2 $\alpha$ (Figure 4A; additional file 1C). Translation of transcription factor ATF4 is controlled by p-eIF $2 \alpha$. When transcript level of ATF4 was measured, no significant changes were observed after 3 hours. After 24 and 48 hours, palmitate caused 3-fold induction in the expression level of ATF4 (Figure 4C). Again, these alterations were independent on glucose concentration or addition of AICAR or etomoxir. CHOP is a downstream target of ATF4. It has proapoptotic properties and regulates expression of another apoptotic factor, GADD34 [31]. Expression level of CHOP transcript (not shown) and protein (Figure 4D; additional file 1C) as well as GADD34 transcript (Figure 4E) were very similar to that of ATF4. When IRE1 and ATF6 signaling were examined in INS-1E cells exposed to palmitate, no significant alterations in the expression level of pathway markers, sXBP1 (Figure 4F), EDEM (Figure 4G) and BiP (Figure $4 \mathrm{H}$; additional file $1 \mathrm{C}$ ), were observed irrespective of time, glucose, AICAR or etomoxir concentrations. 


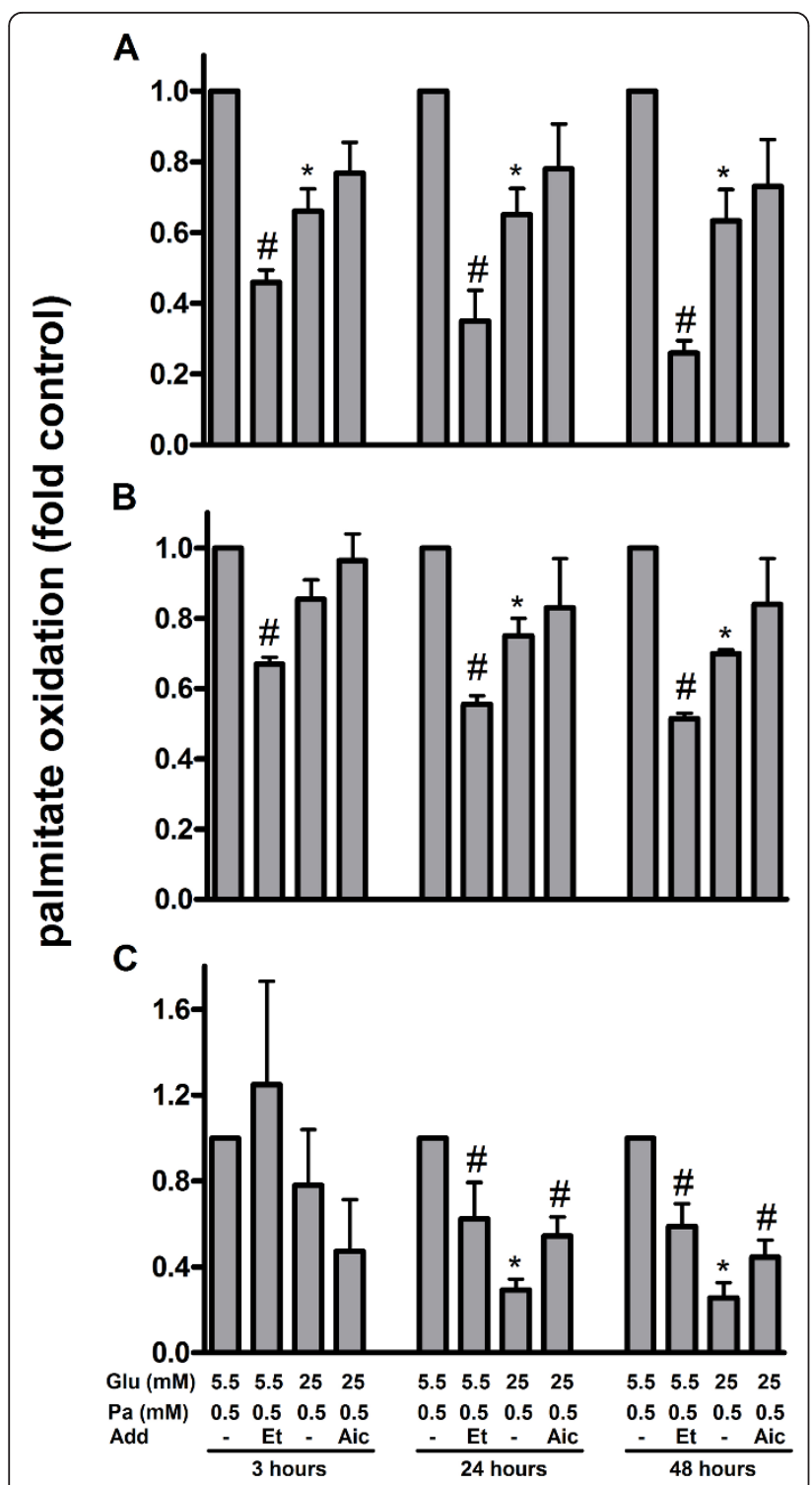

Figure 1 Palmitate oxidation in palmitate-exposed human islets (A), MIN6 cells (B) and INS-1E cells (C). The cells and islets were cultured for 3,24 and 48 hours in the presence of $0.5 \mathrm{mM}$ palmitate (Pa) and $2 \mu \mathrm{Ci}\left[{ }^{3} \mathrm{H}\right]$ palmitate per $\mathrm{ml}$ at 5.5 or $25 \mathrm{mM}$ glucose (Glu). AICAR ( $1 \mathrm{mM}$; Aic) or etomoxir ( $0.2 \mathrm{mM}$; Et) were added as indicated. Islets cultured at $5.5 \mathrm{mM}$ glucose; MIN6 cells cultured at $25 \mathrm{mM}$ glucose and INS-1E cells cultured at $11 \mathrm{mM}$ glucose alone were considered as controls. After culture, media were collected, ${ }^{3} \mathrm{H}_{2} \mathrm{O}$ separated and radioactivity determined by a liquid-scintillation spectrometer. Results are means \pm SEM of 3-4 independent experiments. * $\mathrm{P}<0.05$ compared to low glucose and $\# \mathrm{p}<0.05$ effect of additive.

When markers of the UPR were compared with palmitate oxidation in INS-1E cells, MIN6 cells or human islets, no correlation was observed.

\section{Discussion}

ER stress and activation of UPR has been suggested as a mechanism of how raised nutrient levels exert their

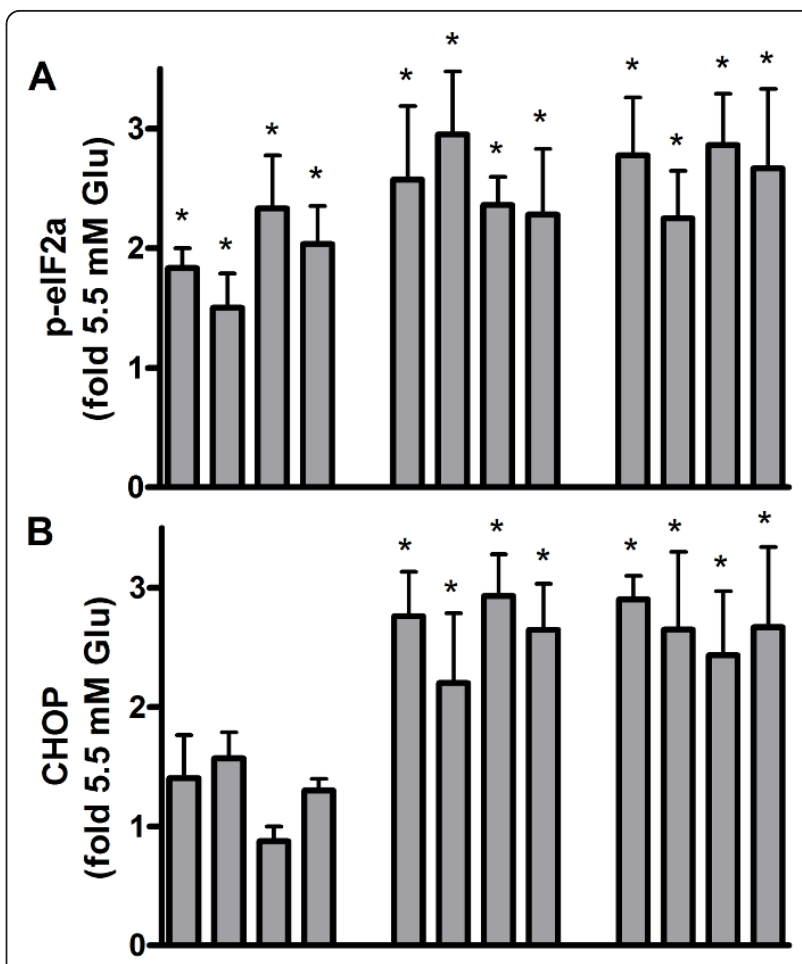

C

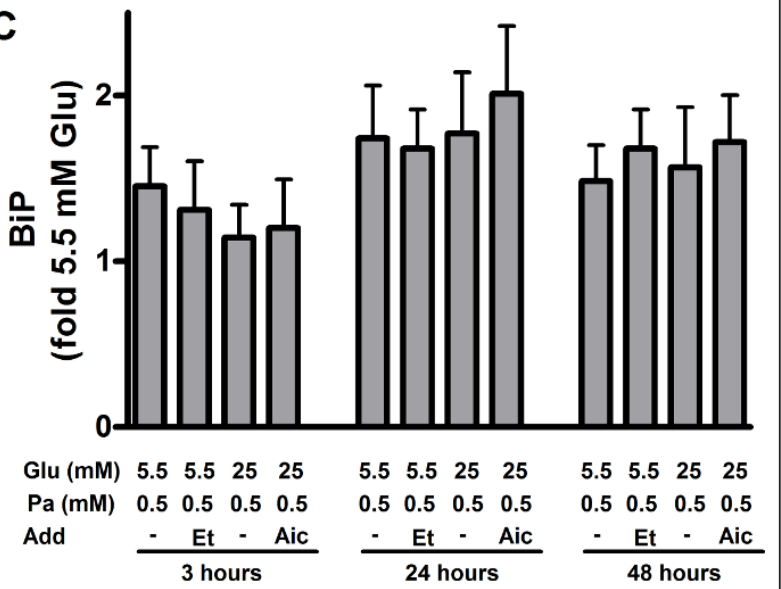

Figure 2 Unfolded protein response in palmitate-exposed human islets. The islets were cultured for 3, 24 or 48 hours in the presence of $0.5 \mathrm{mM}$ palmitate $(\mathrm{Pa})$ at 5.5 or $25 \mathrm{mM}$ glucose (Glu). AICAR (1 mM, Aic) or etomoxir $(0.2 \mathrm{mM}$, Et) were added as

indicated. Islets cultured at $5.5 \mathrm{mM}$ glucose alone were considered as control. After culture, protein levels of p-elF2 $\alpha$ (A), CHOP (B) and $\mathrm{BiP}(\mathrm{C})$ were measured. Protein levels are means \pm SEM of 4 independent experiments. ${ }^{*} \mathrm{P}<0.05$ compared to control.

detrimental effects on palmitate-treated beta-cells. Support for a role of ER stress in lipotoxicity via activation of the UPR has been supplied by studies, where manifestations of the UPR were recorded in beta-cells undergoing apoptosis as a consequence of exposure to palmitate $[4-7,9,10]$. In triggering ER stress saturated fatty acids such as palmiate are much more potent than unsaturated fatty acids, such as oleate [32]. In line with 

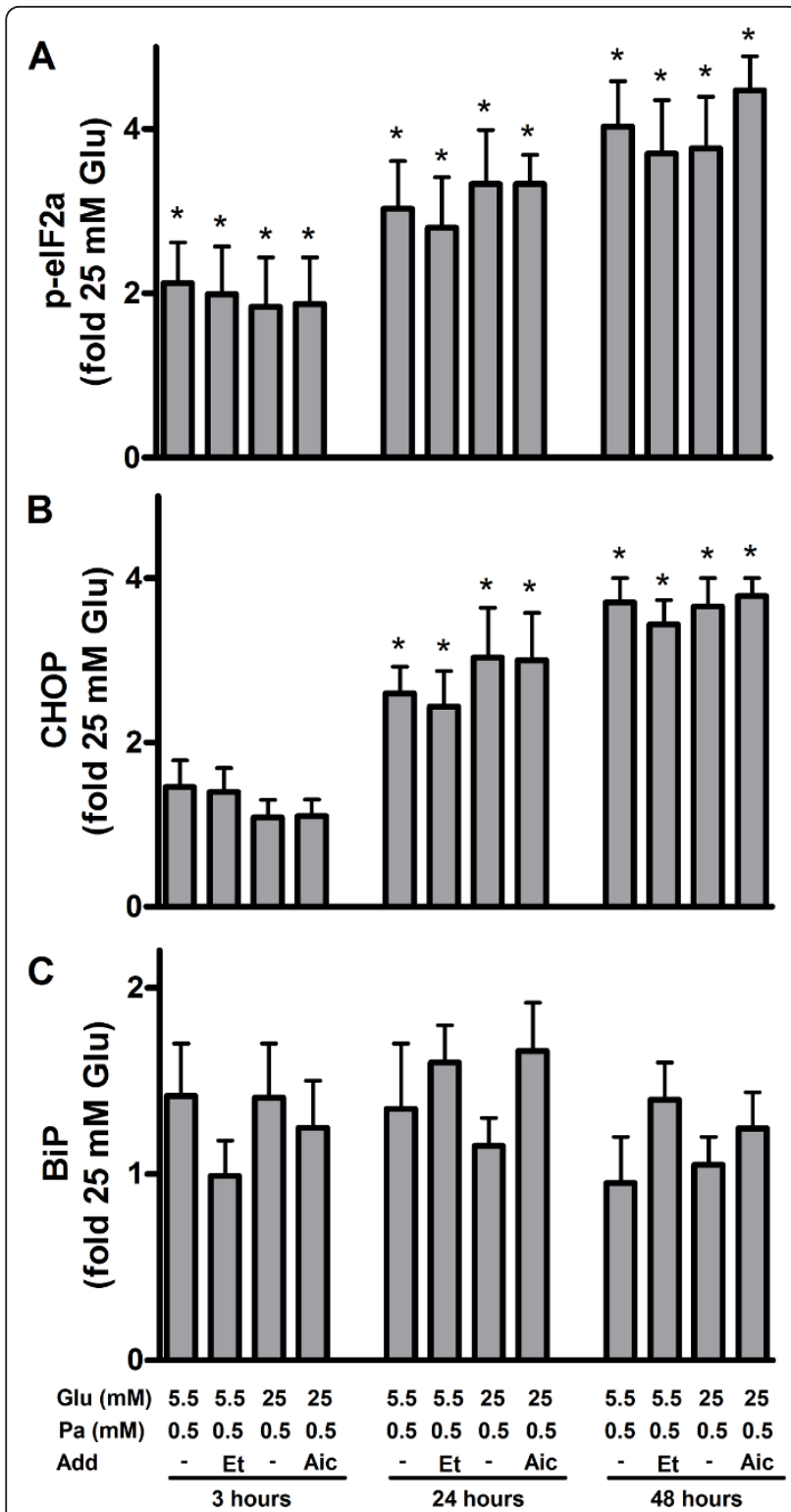

Figure 3 Unfolded protein response in palmitate-exposed MIN6 cells. The cells were cultured for 3, 24 and 48 hours in the presence of $0.5 \mathrm{mM}$ palmitate $(\mathrm{Pa})$ at 5.5 or $25 \mathrm{mM}$ glucose (Glu). AICAR (1 mM, Aic) or etomoxir (0.2 mM, Et) were added as indicated. Cells cultured at $25 \mathrm{mM}$ glucose alone were considered as control. After culture, protein levels of p-elF2 $\alpha$ (A), CHOP (B) and $\mathrm{BiP}(\mathrm{C})$ were measured. Protein levels are means \pm SEM of 4 independent experiments. ${ }^{*} \mathrm{P}<0.05$ compared to control.

this, knocking-down SCD1 in palmitate-treated betacells aggravates the toxic effect of the saturated fatty acid [33].

The mechanisms of how fatty acids induce ER stress are yet unclear. Some authors hypothesize that prolonged exposure to palmitate causes ER $\mathrm{Ca}^{2+}$ release, which disturbs ER homeostasis and causes ER stress $[24,34]$. However, it is unlikely that the observed modest depletion of ER $\mathrm{Ca}^{2+}$ may lead to ER stress [4]. Another argument against this hypothesis is that release of ER $\mathrm{Ca}^{2+}$ was observed in cells treated with oleate, which does not induce ER stress [24,34]. ER protein overload is another mechanism, which may contribute to ER stress in lipotoxic beta-cells. Recent studies showed that protein overload might be a consequence of reduced ER-to-Golgi protein trafficking or degradation of carboxypeptidase E $[35,36]$. However, absence of significant changes in the expression level of molecular chaperones, such as BiP, in the current and previous studies makes this hypothesis questionable $[4,10,11]$. Up-regulation of ER chaperones is a major response to accumulation of unfolded protein in the ER. The protective role of $\mathrm{BiP}$ is also questioned in the study, where over-expression of BiP in INS-1 cells and MIN6 cells partially reduced susceptibility to thapsigargin but failed to reduce palmitateinduced ER stress [6]. Furthermore, gene expression analysis did not detect changes in mRNA level of ER chaperones in palmitate-treated beta-cells [37]. It should also be mentioned that in some studies results concerning expression and role of $\mathrm{BiP}$ in palmitate-treated betacells are opposite. Thus, Kharroubi et al. demonstrated palmitate-induced up-regulation of BiP mRNA level connected with enhanced apoptosis [5]. Also, Laybutt et al. observed protective, ER stress-reducing and antiapoptotic effects of BiP over-expression [7].

Prolonged exposure to palmitate leads to formation of tripalmitin [18]. It was shown that tripalmitin accumulates in the ER rather than in the cytoplasm of the betacells. This is in contrast to oleate, which forms droplets in the cytoplasm [18]. Accumulation of insoluble tripalmitin may cause morphological perturbations in the ER and be toxic for the beta-cells $[17,18]$. We hypothesized that reducing fatty acid oxidation would accentuate ER stress by increasing generation and incorporation of tripalmitin into microsomes. To reduce metabolism we raised glucose, which inhibits palmitate oxidation and shuttles the fatty acid to non-oxidative pathways [20,23]. Also, we used AMPK activator AICAR that stimulates, and CPT1 inhibitor etomoxir that inhibits oxidation $[19,22,23]$. Fatty acid oxidation was higher at low glucose compared to high glucose concentration both in cell lines and human islets, but especially pronounced in INS-1E cells. Accentuated glucose-induced reduction in palmitate oxidation in INS cells was also observed in previous studies [23,38]. More efficient oxidation of fatty acids by MIN6 cells and human islets compared to INS-1E cells in the presence of high glucose might be explained by higher activity of ACC in INS-1E cells [23]. The accentuated glucose-induced reduction in palmitate oxidation in INS-1E cells may explain the significant effect of AICAR in these cells. Surprisingly, essentially similar activation of UPR by palmitate was observed 


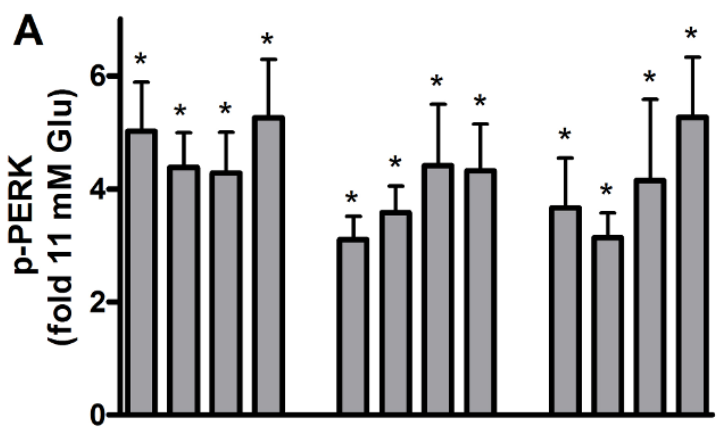

B

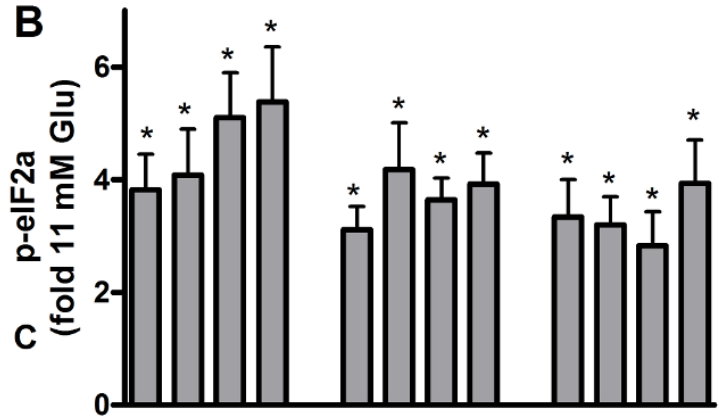

C

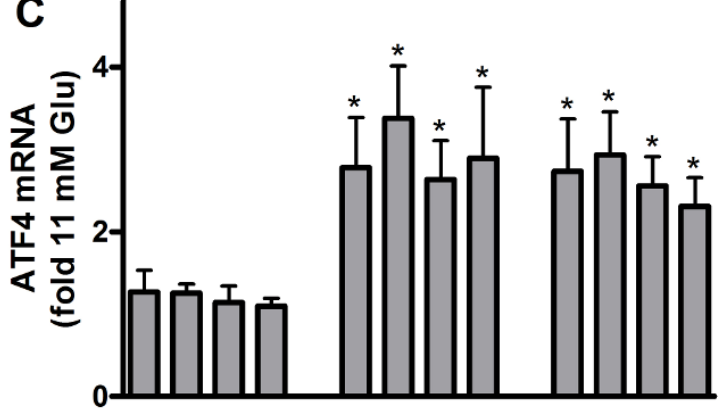

D

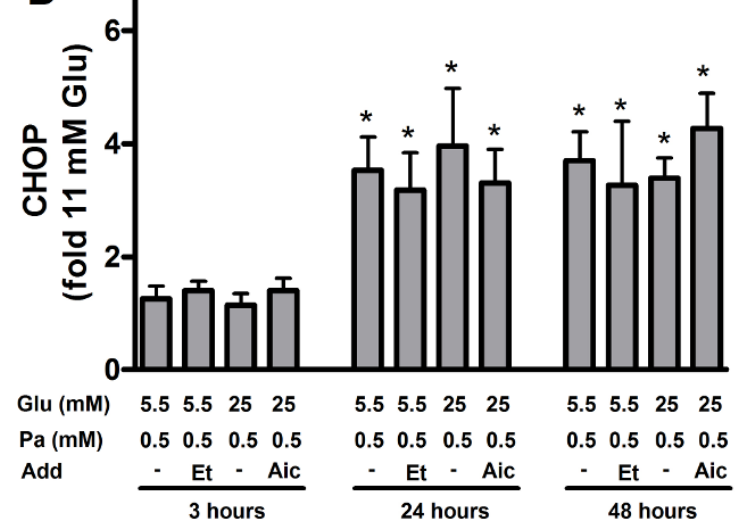

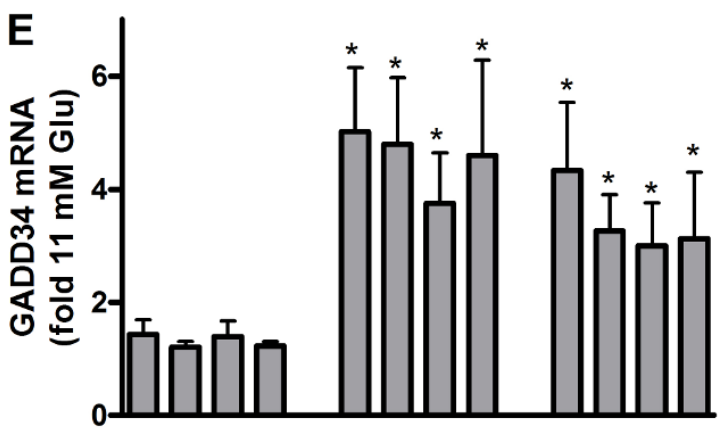

$\mathbf{F}$

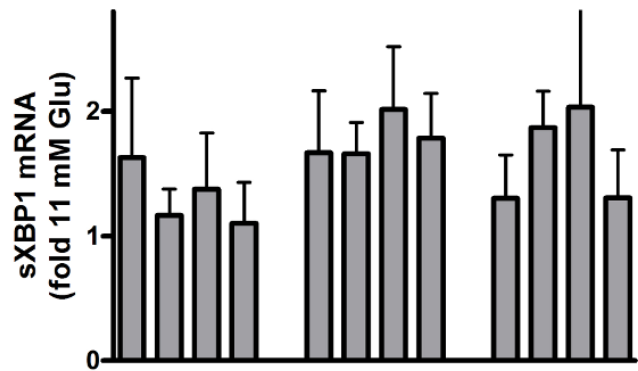

G

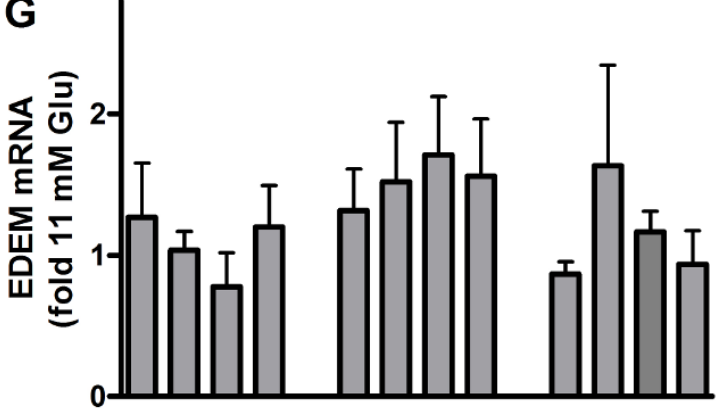

H

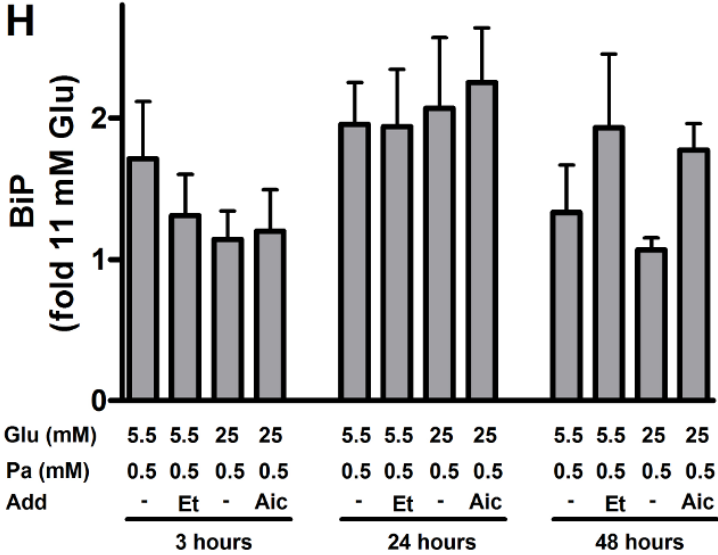

Figure 4 Unfolded protein response in palmitate-exposed INS-1E cells. The cells were cultured for 3, 24 or 48 hours in the presence of 0.5 $\mathrm{mM}$ palmitate $(\mathrm{Pa})$ at 5.5 or $25 \mathrm{mM}$ glucose (Glu). AICAR (1 mM, Aic) or etomoxir (0.2 mM, Et) were added as indicated. Cells cultured at $11 \mathrm{mM}$ glucose alone were considered as control. After culture, protein levels of p-PERK (A), p-elF2 $\alpha$ (B), CHOP (D), BiP (H) and transcript levels of ATF4 (C), GADD34 (E), sXBP1 (F) and EDEM (G) were measured. Protein and transcripts levels are means \pm SEM of 6 independent experiments. *P < 0.05 compared to control. 
both at low and high glucose concentrations. Furthermore, stimulation and inhibition of palmitate oxidation by AICAR and etomoxir did not affect palmitateinduced UPR activation. This holds true for both cell lines and human islets. More robust activation of UPR markers in INS-1E cells may speak in favor of higher sensitivity of these cells to palmitate exposure.

Previous data on the role of glucose and fatty acid metabolism in palmitate-induced ER stress response are controversial. While Bachar et al claimed that glucose amplified ER stress [39], Cunha et al showed that glucose did not amplify ER stress in palmitate-treated beta-cells [24]. The discrepancy was suggested to be explained by the fact that protein and mRNA levels of ER stress markers were analyzed by the respective groups. Inhibition of CPT1 by siRNA approach performed by Choi et al caused increased expression of CHOP but decreased phosphorylation of eIF2 $\alpha$ and JNK [40].

\section{Conclusions}

Our finding suggests that factors other than palmitate oxidation play major role in the palmitate-induced activation of UPR. Furthermore, the fact that apoptosis in beta-cells depends on the oxidation of palmitate suggests that the UPR is not a major mechanism by which the fatty acid negatively affects the beta-cell. The mechanisms by which palmitate activates UPR and its role in the induction of apoptosis requires additional studies.

\section{Additional material}

Additional file 1: Representatives gels of WB in human islets (A), MIN6 cells (B) and INS-1E cells (C). The cells and islets were cultured for 3 and 48 hours in the presence of $0.5 \mathrm{mM}$ palmitate ( $\mathrm{Pa}$ ) at 5.5 or 25 $\mathrm{mM}$ glucose (Glu). AICAR ( $1 \mathrm{mM}$; Aic) or etomoxir $(0.2 \mathrm{mM}$; Et) were added as indicated. Islets cultured at $5.5 \mathrm{mM}$ glucose, MIN6 cells cultured at $25 \mathrm{mM}$ glucose and INS-1E cells cultured at $11 \mathrm{mM}$ glucose alone were considered as controls. After culture, proteins were isolated and subjected to immunoblot analyses with antibodies towards p-PERK (C), p-elF2 $\alpha(A ; B ; C), C H O P(A ; B ; C)$ and BiP (A;B;C).

\begin{abstract}
Acknowledgements
Grants from the Swedish Medical Research Council (72X-14019), Swedish Diabetes Association, Family Ernfors Foundation, Uppsala University and Fredrik and Ingrid Thurings foundation supported the study.
\end{abstract}

\section{Authors' contributions}

ES participated in the design of the study, carried out all the studies, analyzed the data and drafted the manuscript. EMS performed some WB experiments. PB helped to draft the manuscript. All authors have read and approved the final manuscript.

\section{Competing interests}

The authors declare that they have no competing interests.

Received: 14 July 2011 Accepted: 6 October 2011

Published: 6 October 2011

\section{References}

1. Haber EP, Procopio J, Carvalho CR, Carpinelli AR, Newsholme P, Curi R: New insights into fatty acid modulation of pancreatic beta-cell function. Int Rev Cytol 2006, 248:1-41.

2. Robertson RP, Harmon J, Tran PO, Poitout V: Beta-cell glucose toxicity, lipotoxicity, and chronic oxidative stress in type 2 diabetes. Diabetes 2004, 53(Suppl 1):S119-124.

3. Elouil H, Bensellam M, Guiot Y, Vander Mierde D, Pascal SM, Schuit FC, Jonas JC: Acute nutrient regulation of the unfolded protein response and integrated stress response in cultured rat pancreatic islets. Diabetologia 2007, 50:1442-1452.

4. Karaskov E, Scott C, Zhang L, Teodoro T, Ravazzola M, Volchuk A: Chronic palmitate but not oleate exposure induces endoplasmic reticulum stress, which may contribute to INS-1 pancreatic beta-cell apoptosis. Endocrinology 2006, 147:3398-3407.

5. Kharroubi I, Ladriere L, Cardozo AK, Dogusan Z, Cnop M, Eizirik DL: Free fatty acids and cytokines induce pancreatic beta-cell apoptosis by different mechanisms: role of nuclear factor-kappaB and endoplasmic reticulum stress. Endocrinology 2004, 145:5087-5096.

6. Lai E, Bikopoulos G, Wheeler MB, Rozakis-Adcock M, Volchuk A: Differential activation of ER stress and apoptosis in response to chronically elevated free fatty acids in pancreatic beta-cells. Am J Physiol Endocrinol Metab 2008, 294:E540-550.

7. Laybutt DR, Preston AM, Akerfeldt MC, Kench JG, Busch AK, Biankin AV, Biden TJ: Endoplasmic reticulum stress contributes to beta cell apoptosis in type 2 diabetes. Diabetologia 2007, 50:752-763.

8. Lipson KL, Fonseca SG, Ishigaki S, Nguyen LX, Foss E, Bortell R, Rossini AA, Urano F: Regulation of insulin biosynthesis in pancreatic beta cells by an endoplasmic reticulum-resident protein kinase IRE1. Cell Metab 2006, 4:245-254

9. Wang $H$, Kouri $G$, Wollheim CB: ER stress and SREBP-1 activation are implicated in beta-cell glucolipotoxicity. J Cell Sci 2005, 118:3905-3915.

10. Sargsyan $E$, Ortsater $H$, Thorn $K$, Bergsten P: Diazoxide-induced beta-cell rest reduces endoplasmic reticulum stress in lipotoxic beta-cells. $J$ Endocrinol 2008, 199(1):41-50.

11. Sol ER, Sargsyan E, Akusjarvi G, Bergsten P: Glucolipotoxicity in INS-1E cells is counteracted by carnitine palmitoyltransferase 1 over-expression. Biochem Biophys Res Commun 2008, 375:517-521.

12. Kaufman RJ: Stress signaling from the lumen of the endoplasmic reticulum: coordination of gene transcriptional and translational controls. Genes Dev 1999, 13:1211-1233.

13. Malhotra JD, Kaufman RJ: The endoplasmic reticulum and the unfolded protein response. Semin Cell Dev Biol 2007, 18:716-731.

14. Mori K: Tripartite management of unfolded proteins in the endoplasmic reticulum. Cell 2000, 101:451-454.

15. Patil C, Walter P: Intracellular signaling from the endoplasmic reticulum to the nucleus: the unfolded protein response in yeast and mammals. Curr Opin Cell Biol 2001, 13:349-355

16. Kim R, Emi M, Tanabe K, Murakami S: Role of the unfolded protein response in cell death. Apoptosis 2006, 11:5-13.

17. Borradaile NM, Han X, Harp JD, Gale SE, Ory DS, Schaffer JE: Disruption of endoplasmic reticulum structure and integrity in lipotoxic cell death. $J$ Lipid Res 2006, 47:2726-2737.

18. Moffitt JH, Fielding BA, Evershed R, Berstan R, Currie JM, Clark A: Adverse physicochemical properties of tripalmitin in beta cells lead to morphological changes and lipotoxicity in vitro. Diabetologia 2005, 48:1819-1829.

19. El-Assaad W, Buteau J, Peyot ML, Nolan C, Roduit R, Hardy S, Joly E, Dbaibo G, Rosenberg L, Prentki M: Saturated fatty acids synergize with elevated glucose to cause pancreatic beta-cell death. Endocrinology 2003, 144:4154-4163.

20. Prentki M, Vischer S, Glennon MC, Regazzi R, Deeney JT, Corkey BE: Malonyl-CoA and long chain acyl-CoA esters as metabolic coupling factors in nutrient-induced insulin secretion. J Biol Chem 1992, 267:5802-5810.

21. Berne C: The metabolism of lipids in mouse pancreatic islets. The biosynthesis of triacylglycerols and phospholipids. Biochem J 1975, 152:667-673.

22. Paumen MB, Ishida $Y$, Muramatsu M, Yamamoto M, Honjo T: Inhibition of carnitine palmitoyltransferase I augments sphingolipid synthesis and palmitate-induced apoptosis. J Biol Chem 1997, 272:3324-3329. 
23. Sargsyan E, Bergsten P: Lipotoxicity is glucose-dependent in INS-1E cells but not in human islets and MIN6 cells. Lipids Health Dis 2011, 10:115.

24. Cunha DA, Hekerman P, Ladriere L, Bazarra-Castro A, Ortis F, Wakeham MC, Moore F, Rasschaert J, Cardozo AK, Bellomo E, Overbergh L, Mathieu C, Lupi R, Hai T, Herchuelz A, Marchetti P, Rutter GA, Eizirik DL, Cnop M: Initiation and execution of lipotoxic ER stress in pancreatic beta-cells. J Cell Sci 2008, 121:2308-2318.

25. Folch J, Lees M, Sloane Stanley GH: A simple method for the isolation and purification of total lipides from animal tissues. J Biol Chem 1957, 226:497-509.

26. Nyblom H, Sargsyan E, Bergsten P: AMPK agonist AICAR dosedependently improves function and reduces apoptosis in glucotoxic \{beta\}-cells without changing triglyceride levels. J Mol Endocrinol 2008, 41(3):187-94.

27. Kolodziej MP, Crilly PJ, Corstorphine CG, Zammit VA: Development and characterization of a polyclonal antibody against rat liver mitochondrial overt carnitine palmitoyltransferase (CPT I). Distinction of CPT I from CPT II and of isoforms of CPT I in different tissues. Biochem J 1992, 282(Pt 2):415-421.

28. Livak KJ, Schmittgen TD: Analysis of relative gene expression data using real-time quantitative PCR and the 2(-Delta Delta C(T)) Method. Methods 2001, 25:402-408.

29. Harding HP, Zhang Y, Ron D: Protein translation and folding are coupled by an endoplasmic-reticulum-resident kinase. Nature 1999, 397:271-274.

30. Zinszner H, Kuroda M, Wang X, Batchvarova N, Lightfoot RT, Remotti H, Stevens $\lrcorner$, Ron D: CHOP is implicated in programmed cell death in response to impaired function of the endoplasmic reticulum. Genes Dev 1998, 12:982-995.

31. Marciniak SJ, Yun CY, Oyadomari S, Novoa I, Zhang Y, Jungreis R, Nagata $K$, Harding HP, Ron D: CHOP induces death by promoting protein synthesis and oxidation in the stressed endoplasmic reticulum. Genes Dev 2004, 18:3066-3077.

32. Thorn K, Bergsten P: Fatty acid-induced oxidation and triglyceride formation is higher in insulin-producing MIN6 cells exposed to oleate compared to palmitate. J Cell Biochem 2010, 111:497-507.

33. Thorn K, Hovsepyan M, Bergsten P: Reduced levels of SCD1 accentuate palmitate-induced stress in insulin-producing beta-cells. Lipids Health Dis 2010, 9:108.

34. Gwiazda KS, Yang TL, Lin Y, Johnson JD: Effects of palmitate on ER and cytosolic Ca2+ homeostasis in beta-cells. Am J Physiol Endocrinol Metab 2009, 296:E690-701.

35. Jeffrey KD, Alejandro EU, Luciani DS, Kalynyak TB, Hu X, Li H, Lin Y, Townsend RR, Polonsky KS, Johnson JD: Carboxypeptidase E mediates palmitate-induced beta-cell ER stress and apoptosis. Proc Natl Acad Sci USA 2008, 105:8452-8457.

36. Preston AM, Gurisik E, Bartley C, Laybutt DR, Biden TJ: Reduced endoplasmic reticulum (ER)-to-Golgi protein trafficking contributes to ER stress in lipotoxic mouse beta cells by promoting protein overload. Diabetologia 2009, 52:2369-2373.

37. Busch AK, Cordery D, Denyer GS, Biden TJ: Expression profiling of palmitate- and oleate-regulated genes provides novel insights into the effects of chronic lipid exposure on pancreatic beta-cell function. Diabetes 2002, 51:977-987.

38. Roduit R, Nolan C, Alarcon C, Moore P, Barbeau A, Delghingaro-Augusto V Przybykowski E, Morin J, Masse F, Massie B, Ruderman N, Rhodes C, Poitout $\mathrm{V}$, Prentki $\mathrm{M}$ : A role for the malonyl-CoA/long-chain acyl-CoA pathway of lipid signaling in the regulation of insulin secretion in response to both fuel and nonfuel stimuli. Diabetes 2004, 53:1007-1019.

39. Bachar E, Ariav Y, Ketzinel-Gilad M, Cerasi E, Kaiser N, Leibowitz G: Glucose amplifies fatty acid-induced endoplasmic reticulum stress in pancreatic beta-cells via activation of mTORC1. PLOS ONE 2009, 4:e4954.

40. Choi SE, Jung IR, Lee YJ, Lee SJ, Lee JH, Kim Y, Jun HS, Lee KW, Park CB, Kang $Y$ : Stimulation of lipogenesis as well as fatty acid oxidation protects against palmitate-induced INS-1 beta-cell death. Endocrinology 2011, 152:816-827.

doi:10.1186/1743-7075-8-70

Cite this article as: Sargsyan et al: UPR in palmitate-treated pancreatic beta-cells is not affected by altering oxidation of the fatty acid. Nutrition \& Metabolism 2011 8:70

\section{Submit your next manuscript to BioMed Central and take full advantage of:}

- Convenient online submission

- Thorough peer review

- No space constraints or color figure charges

- Immediate publication on acceptance

- Inclusion in PubMed, CAS, Scopus and Google Scholar

- Research which is freely available for redistribution

Submit your manuscript at www.biomedcentral.com/submit
Ciomed Central 